To cite this article: Allahde Shehu (2020) Western Education Versus Indigenous Knowledge of the Tarok in Plateau State, Nigeria. Information Impact: Journal of Information and Knowledge Management, 11:4, 59-68, DOI: https://dx.doi.org/10.4314/iijikm.v11i4.6

To link to this article: https://dx.doi.org/10.4314/iijikm.v11i4.6

\title{
Western Education versus Indigenous Knowledge of the Tarok in Plateau State, Nigeria
}

\author{
Allahde Shehu \\ Bingham University, Nigeria
}

\begin{abstract}
This paper advocates the need for the preservation and conservation of Indigenous Knowledge of the Tarok in Plateau State, Nigeria. The paper started by discussing western education and the indigenous knowledge of the Tarok people and the possible threat of indigenous knowledge extinction due to lack of written records and problems associated with preservation and conservation of the knowledge. The paper also looked at the brief history of Tarok People, the philosophical basis of the Tarok indigenous knowledge/education, the differences and similarities between Tarok indigenous knowledge and western education, and the aspect of the Tarok indigenous knowledge. Finally, the paper concluded that the Tarok indigenous knowledge was more practical than the western education and that the indigenous type of education had a bearing to the traditions, norms and culture of the people. The paper also recommended among others, the establishment of Tarok indigenous knowledge resource centres (museum) and written record on Tarok indigenous knowledge to avoid the threat of extinction.
\end{abstract}

Keywords Western Education, Indigenous Knowledge, Preservation, Tarok

CONTACT Allahde Shehu allahde@binghamuni.edu.ng Bingham University, Nigeria 2020 The Author Published with License by Information Impact 


\section{Introduction}

Education existed as early as man's history. It existed for a long time as human beings started living in communities in Africa. This education is referred to as indigenous knowledge education. We find evidence of possession of knowledge, skills and way of life from oral tradition of the indigenous communities. However, western education was introduced to Africa by the Christian church missionaries, who had the notion that Africans where entirely uneducated. Ranasinghe (2015) defined education as a condition of human survival. It is also the means where one generation transmits the wisdom, knowledge and experience which prepares the next generation for life's duties and challenges. Before the introduction of western education in Africa, there exists indigenous knowledge or indigenous education.

Makinde et.al (2013), posits that Indigenous knowledge (IK), is also refer to as 'traditional knowledge' (TK) 'traditional environmental knowledge' (TEK) 'local knowledge' (LK) Indigenous education (IE) and local knowledge generally refers to knowledge systems rooted in the cultural traditions of regional, indigenous, or local communities. Traditional knowledge is held by traditional community that is based on their experience and adaptation to a local culture and setting which includes types of knowledge about traditional technologies of subsistence agriculture, animal husbandry and ethnic veterinary medicine, use and management of natural resources, primary health care system (PHC), preventive medicine and psychosocial care, saving and lending, community development, poverty alleviation midwifery, ethno-botany and ecological knowledge, celestial navigation, ethnoastronomy, the climate, etc. These kinds of knowledge are crucial for the subsistence of the various local communities and survival are generally based on accumulations of empirical observation and interaction with the environment. (Warren, 1991, Edsand, \& Broich, 2019).

Indigenous knowledge is knowledge that has been orally passed from generation to generation and from person to person. Most of the Indigenous knowledge, unlike the western educational system are expressed through stories, legends, folklore, rituals, songs and even laws (Zuckermann, 2015). Other forms of traditional knowledge are expressed through different means. Indigenous societies are often remote and isolated from one another and their development has occurred relatively independently, so their identities are far more varied than in those of contemporary knowledge. Johnson (1992) identifies the following characteristic features of IK: It is locally bound, i.e. indigenous to a specific area. - It is culture and context specific. • It is non-formal. • It is orally transmitted and generally not documented. - It is dynamic and adaptive, not static, changing as the society changes socially, economically, culturally, etc. $\bullet$ It is holistic in nature. $\bullet$ It is closely related to the survival and subsistence of many people worldwide. - It belongs to the community; the knowledge is communally owned. Based on the above, it can be concluded that IK is scientific in the sense that it is obtained through many years of practicing and therefore provides scientific solutions to problems that communities are facing. IK belongs to the particular community; it is there for helping to solve people's problems and it is to be shared communally. Those who acquire the knowledge acquire it on behalf of the community. IK is meant to benefit all the people in the community.

IK can also be drawn from a broad array of disciplines, such as: $\bullet$ Environmental conservation - Traditional education systems $\bullet$ Health practices and prevention $\bullet$ Medical technology $\bullet$ Sustainable agricultural practices $\bullet$ Local industry and technology, and many other areas.(Covin \& Stivers, 1997, Msoffe, 2013). The problem, however, is how the local knowledge practices, principles and methodologies are appreciated and applied. Whereas modern scientific knowledge generated through scientific research processes is highly appreciated, in many respects, IK is still questionable.

In the emerging global knowledge economy a country's ability to build and mobilize knowledge capital, is equally essential for sustainable development as the availability of physical and financial capital. (World Bank, 1997) The basic component of any country's knowledge system is its indigenous knowledge. It encompasses the skills, experiences and insights of people, applied to 
maintain or improve their livelihood. Significant contributions to worldwide knowledge have originated from aboriginal people, for instance in medicine and other related profession with their intimate understanding of their environments. IK is developed and adapted constantly to gradually changing environments and passed down from generation to generation and intimately interconnected with people's cultural values. IK is also the community wealth of the poor, their major asset to invest in the struggle for survival, that is to produce their basic needs which are food, shelter, cloth and to from control by other people.

The contemporary issues and modern technology has put most of the indigenous systems at risk of becoming extinct because of rapidly changing natural environments and fast pacing economic, political, and cultural changes on a global scale. Practices are becoming extinct as they become inappropriate for new challenges or because they adapt too slowly. However, many practices disappear only because of the intrusion of foreign technologies or development concepts that promise short-term gains or solutions to problems without being capable of sustaining them. The tragic of the impending disappearance of IK is most obvious to those who have developed it, as a result necessitate this study. This paper, therefore examines the western education versus indigenous knowledge of the Tarok in Plateau State, Nigeria. Consequently, indigenous knowledge is being lost under the impact of modernization and the ongoing globalisation processes. It is very important, therefore, to protect and further develop the knowledge generated and perpetuated by local communities through deliberate policy and institutional reform programmes. Moreover, reasoning and rapid development is attained through the language and customs the people know and express themselves best.

\section{Statement of the problem}

Indigenous knowledge plays a fundamental role in the societies that are often remote and isolated from one another and their development has occurred relatively independently. It is the knowledge that has been orally passed from generation to generation and from person to person. Most of the Indigenous knowledge, unlike the western educational system are expressed through stories, legends, folklore, rituals, songs and even laws (Johnson,1992). Before the advent of western education in Tarok land, there was indigenous knowledge or indigenous education. However, with the coming of western education, the indigenous knowledge of the Tarok people is gradually going extinction due to lack of written records and problems associated with preservation and conservation of the knowledge. In view of the above, this study seeks to find out the level of extinction of the indigenous knowledge of the Tarok people.

\section{Objectives of the study}

The main objective of this study is to find out the influence of western education on indigenous knowledge of the Tarok people of Plateau State, Nigeria.

- To find out the role of Tarok indigenous knowledge and traditional ways of learning in maintaining the sustainability of their communities.

- To ascertain the differences and the similarities of the Tarok IK and western educational system.

- To identify opportunities for integrating relevant aspects of Tarok indigenous knowledge and approaches to modern technology.

- To record the benefit of the Tarok indigenous knowledge.

- To preserve and conserve the Tarok indigenous knowledge. 


\section{Brief history of Tarok People}

The Tarok people are the indigenous inhabitants of Langtang-North, Langtang-South, Local Government Areas (LGAs). They are also found in Wase, Mikang, Kanke,Shendam, Qua'an-Pan, Kanam and Pankshin LGAs. of Plateau State in Central Nigeria. The main town of Langtang is located about 186 kilometres south-east of Jos, the state capital. Some of the Tarok people have also migrated to Nasarawa and Taraba states for farming activities. Longtau (1995) described Tarok as one of the Benue-Congo languages which is almost completely submerged in a sea of Chadic languages. These languages include Ngas, Tel, Boghom, Hausa / Fulfulde and Yiwom. Its non-Chadic neighbours are Pe, Jukun-Wase and Yangkam. Tarok has spread considerably in the twentieth century and it now borders Wapan in the south-east. The Chadic languages belong to a different language family called Afroasiatic. Longtau explained that Tarok had settled in their present abode long before the eastern and southward movements of Boghom and Ngas respectively. Similarly, the study by Lamle (2005) shows that in the early twentieth century people from other ethnic groups such as Tal, Ngas, Jukun, Tel (Montol/Dwal) and Yiwom (Garkawa) migrated and settled together with the initial Timwat and Funyallang clans. People from these ethnic groups came as migrants labour workers. The Timwat and Funyallang people gave them land to settle (Nandip, 2016).

The Tarok is a merger of a variety of peoples who forms an additional 'homogenous' group. The groups were of Pe, Ngas, Jukun, Boghom, Tel (Montol) and most likely Tal Origins, and others remain unknown (Aluwong, 2019). The Tarok people have an ancestral cult which retains considerable prestige and importance, despite the advent of Christianity into the area. The ancestors, orìm, activities are restricted to the initiated males and post-menopausal women. Cult activities take place in sacred groves outside almost all Tarok settlements. Each Tarok settlement of any size has a sacred grove outside it, which is conserved as the place of the orim or ancestors. The singular form, ùrìm, is applied to a dead person or an ancestor, while orìm refers to the collective ancestors and the cult itself. Men above a certain age of reasoning are allowed to enter the grove and engage with the ancestors. These inhabit the land of the dead and are thus in contact with all those who have died, including young people and children who were not admitted to the orìm. On certain nights when the 'orìm are out', women and children must stay in their houses. The main function of the orim is to maintain order, both spiritual and physical, within the society and also to prepare for warfare and other collective action. However, most Tarok are Christians and Langtang hosts some large churches, but the association of the orìm with power ensures that these two systems continue to coexist.

The Tarok people are predominantly farmers and pastoralists. They interact directly with the environment from childhood, thereby, acquiring a great deal of indigenous knowledge of their environment. They are also familiar with every plant in their locality and they can describe the palatability of each plant for human consumption and for the different animals they keep, and they know each plant's season, nutritional value, toxicity and medicinal value. Tarok IK is embedded in community practices, institutions, relationships and rituals. One of the challenges of IK of the Tarok people as pointed out earlier is that most of the IK are not available in written form. It is mainly found in practice and is transmitted verbally from generation to generation. This renders its preservation difficult.

\section{Preservation and Conservation of Tarok Indigenous Knowledge}

Preservation is "the act of safeguarding, protecting or keeping in safety or security from harm, injury, decay, or destruction of library and archival collections" (Yunus \& Yunus, 2017). Preservation of Tarok indigenous knowledge involves all the measures and actions put together to ensure that the culture and ways of lives of the Tarok people are not distorted or corrupted by the advent of modern education or civilization. Preservation also has to do with the storage or documentation of stories, 
legends, folklore, rituals, songs, and even laws of the Tarok people for the unborn generation. It includes safeguarding both the physical settings of the Tarok's settlement and ways of lives. Oxford Dictionary (1999), gives the meaning of conservation as the prevention of loss, waste, idamage, destruction etc. Yunus and Yunus, (2017) stated that conservation refers to specific practice taken to slow deterioration and prolong the life of an object by direct intervention in the physical or chemical make-up. Conservation of the Tarok IK is the bringing back to life some of the cultures and ways of lives of the people that are gradually fading away or going extinct. It is also important to distinguish between preservation and conservation. Preservation is to do with the safeguarding the people cultures and ways of lives from decaying or destruction, while, conservation on the other hand means restoring the deteriorated culture and ways of lives of the people.

\section{The Philosophical Base of the Tarok Indigenous Knowledge}

The Tarok indigenous education did not develop in a vacuum, it developed based on the following philosophical premises:

Preparedness: Children are given birth to into different families and they tend to learn the trade or occupation of their parents. It also implies that the role of training and learning was to equip boys and girls with the skills appropriate to their gender in preparation for their distinctive adult roles in the society. In the Tarok traditional societies boys are taught about adult's role in life. In Tarok culture, boys are taught to become warriors, farmers, good fathers, rearing animals, herbs, mud building, knitting, hunting etc. while girls are taught how to become good mothers and how to farm.

Functionalism: The Tarok Indigenous knowledge /education are meant to provide for immediate induction into real life in the society. It is functional because of the knowledge, skills and values that are imparted for socio-economic activities of the individual. This is evident in the fields of agriculture, building, iron smelting, singing and drumming.

Communalism. Another philosophy on the Tarok indigenous knowledge is that works are done based on communal effort. For example during raining season farming is done on communal level called Igaya, which is done on rotational basis. It is worthy of note that if a member falls sick during the season and is not able to participate in the communal work, it is incumbent on the group to farm for him or her throughout the season. The communal work is also done during the dry season, like building and roofing of houses by men and women gathering of fire wood, fixing their kitchen, making clay pots etc. Predominantly, the Tarok people live on communal effort. This is done in order to carry every one along and also support the weaker ones in the community. As part of the Tarok people communal service, they view children upbringing as the whole community's responsibility. In the event that a child misbehaves in the absence of his/her parents, it is incumbent for any adult present there to discipline the child which presupposes that even children belong to the society.

Orderliness: Orderliness is the main thrust of the Tarok people's indigenous knowledge and existence. There are the "dos" and the "don'ts" in every Tarok community, strict discipline and order are highly maintained because for every offence there is a punishment for deterrence. Offences like stealing, adultery, rape, incest, taboos e.t.c are not taken lightly.

Multiple Learning: Another philosophy based of the Tarok indigenous knowledge is that the learner is mandatorily required to obtain multiple skills. For example the boy child learns farming in addition to other skills like, rearing animals, traditional medicine and the use and application of various herbs, building and roof of houses, knitting, hunting etc

Perennialism. This philosophy is based on indigenous knowledge of essential instruments for preserving the culture and ways of lives of the Tarok people. It hinders the young people from accepting foreign ideas; hence it is conservative in nature. 


\section{The Difference between Tarok Indigenous Knowledge and Western Education}

\section{Purpose}

The Tarok indigenous knowledge is handed down from generation to generation. It includes relationships between the people, and is reflected in language, social organization, values, institutions and laws. It also deals with spiritual relationships, relationships with the natural environment and the use of natural resources. On the other hand, the missionaries and the colonial masters who championed the course of western education were concerned mainly with training Nigeria's to make their missionary and colonial assignments easier. In this wise the purpose of the early western education was to train clerks and interpreters to make them read and write in order to serve the missionary and colonial interest. However, the western education later embraces all professional field of human endeavor.

\section{Examination}

Western Education involves writing formal (written) examinations at various stages/level, while there are no formal (written) examinations in the Tarok indigenous education. The Tarok form of education is purely informal in nature

\section{Certification}

Certificates are awarded at the completion of a course under the western education, while no certificates are awarded in indigenous education of the Tarok people.

\section{Language of Instruction}

The Tarok native language is essentially used in the indigenous education of the Tarok people while the main language of instruction in western education in Nigeria is English language.

\section{Method of Instruction}

Instruction in Tarok indigenous education involves everybody in the community(elders, peers, parents, sibling etc) and it is done through imitation, direct observation, role learning, and the use of stories, myths, folklore, tales and taboos, Indigenous education makes use of rote learning, without writing since it is informal education. While, instruction in western education is formalized. It involves the use of writing, reading and at times memorization. Instruction in western education involves direct teaching by designated teachers as well as some practical experience.

\section{Organization and Management}

Indigenous Tarok education is not formalized and it takes place within the community, anytime and anyplace throughout the day. The supervision of the Tarok indigenous education is not limited to the family alone; it comprises everyone in the community (peers, parents, siblings, elders etc). Everyone wants the child to be sociable, honest, courageous, humble, persevering and of good character. Character development is emphasized in the Tarok indigenous education. Whereas western education is formalized and handled by the formal institutions known as schools, it has opening and closing time. Instruction in western education is supervised by designated officials, the teachers handle given subjects in the school curriculum.

\section{Community Integration}

Indigenous Tarok education integrates recipients to the society because the skills learnt are required in the community. It is use for sustaining the family and community development. On the other hand, western education encourages rural-urban migration. Most of the people that acquire western education tend to abandon and disregard their people's culture and ways of life.

\section{Curriculum}

The curriculum of the Tarok indigenous education is not structured but covers all aspects of learning (cognitive, affective and psychomotor). The curriculum is integrated rather than being compartmentalized on sublet basis. It is holistic. While, the curriculum of western education is structured and involves Reading, Writing and Arithmetic, later gardening, music and other subject 
were introduced, the curriculum is compartmentalized on subject basis and instruction is thus formalized.

\section{Employment Prospects}

There is no unemployment in the Tarok indigenous education; this is because the skill required are the ones that are trained by the community. The education is expected to make the individual to be selfreliant after the training they are integrated into the society without formal application for job. On the other hand, western education is characterized by unemployment of school graduates since many of them are interested in white-collar jobs due to the nature of the education received. Entrepreneurship education is emphasized in indigenous education whereas recipient of western education prefers formal office engagement which eventually leaves most youths to be unemployed.

\section{Similarities between Indigenous Knowledge and Modern Education}

Mkandawire, (2005), posits that there are a lot of similarities and differences between the two terms. One of the similarities between indigenous African education and the type of education brought by missionaries is that they had the same purpose of preparing of the young generation into a useful adult life in household, village and tribe. Both educational systems are aimed at bringing up individuals as responsible people in the society. This is done through the transmitting of attitudes, values, skills social understanding and the various customs of the society. Both systems make the individuals functional in the society where they live

- Indigenous knowledge and modern education are aim at equipping the youth on how to perform social functions, respecting of their adults and other people in the society.

- Both types of education prepare individuals for employment in their own environment because they believe that people must have life.

- Indigenous knowledge and modern education accept values and norms such as honesty, generosity, diligence and hospitable as part of civic education.

\section{Aspects of the Tarok Indigenous Knowledge}

\section{Agricultural Science}

In the early Taroks IK, there were vast lands for agriculture with lower population. The people then were predominantly farmers and pastoralists. (Shepherd/herdsmen).Both boys and girls were taught how to farm various crops and they grow up doing it well. Tarok indigenous farming system is also characterized by planting more than one type of crop (intercropping) on the same piece of farmland. The wisdom behind planting more than one crop is to ensure that the entire farm is not devastated in case of disease outbreak or pest attack. They also practiced the bush fallowing system, a situation where the farmers frequently abandon their farm for few years to new farmlands to allow for regrowth of natural vegetation and enrichment of the soil before coming back to it. The people experience difficulties sometimes in farming, which includes the stress of environmental degradation and variability, particularly drought, flooding, deteriorating climatic conditions, and increasing health pressures.

\section{Engineering}

Indigenous engineering was part of the Tarok indigenous education which improves their livelihood through the use of simple implements for farming, hunting, self-defense or war. The equipments/tools were produced by the black smith in the communities. The vocation was predominantly taught to the boys by their fathers or guardian so that the younger generation can take over from the older 
generation. The implements produced by the blacksmith included, hoes, cutlasses, knives, spears, arrow heads, shields e.t.c

\section{Indigenous Medicine}

Indigenous medicine also known as traditional medicine comprises knowledge of medicinal plants of the Tarok people that were developed from generation to generation within the various communities before the era of modern medicine. World Health Organization (2013), defines traditional medicine as "the sum total of the knowledge, skills, and practices based on the theories, beliefs, and experiences indigenous to different cultures, whether explicable or not, used in the maintenance of health as well as in the prevention, diagnosis, improvement or treatment of physical and mental illness."The Tarok indigenous medicine is mostly passed on orally to the younger generation through a family, an individuals or a community. There was hardly any family in Tarok land that did know certain herbs for treatment of some kind of ailment. The fathers who are heads of the families work very closely with their son/sons, to introduce them to the act of indigenous medicine. Mothers also transmit their knowledge of herbs/medicine to their daughters; some of the women specialize as traditional birth attendants.

There are three (3) factors that legitimize the role of the healer in Tarok land

- their own beliefs

- the success of their actions

- the beliefs of the community.

It is worthy of note that when the Tarok indigenous medicine is accepted outside of the aforementioned traditional culture, traditional medicine is often called alternative medicine.

\section{Natural Resources}

Indigenous knowledge and the attitudes of the Tarok have influenced natural resource management of the people. There are many reserves, reservations or forest that are located in areas rich in natural resources, which could provide a culturally appropriate basis for developing tribal economies and cultural benefit in the modern world which are protected by the communities. Most of the reserved forest are sacred that is why they still remain natural as ever. The forest consists of numerous plant species that are not easy to come by as a result of human activities. These sacred forests are places that are respected and reserved for the cultural expression of the communities. The access and management of the forest are governed by traditional powers. For the inhabitants, it serves as protection, providing them with medicinal plants and food and it is a place for the conservation of flora and fauna. It also serves as a last living testimonial for future generations of what a true forest is.

\section{Conflict Management}

The Tarok people have various avenues by which conflict are been managed or settled. The array of ways and avenues by which they settle grievances/clashes of right and wrong, includes the following: Mbin: Is the supreme indigenous court in Tarok land, cases are decided by Elders which are picked from the community, representing their various clans.

Atak Iku- funeral rite is an avenue where pending issues are discussed and settled, if the pending issues defer solution it is then taken to the higher court which is Mbin.

Igaya. It is a communual activities that is aimed at self-help, it encourages bond, it could be farming, building etc disputes are also settled at Igaya.

Achi-pir /Nubuang: Are also avenues where neighbourhood disputes are settled.

\section{Challenges of Indigenous Knowledge in Tarok Land}

One of the challenges of indigenous knowledge of the Tarok people is the threat of extinction. As mentioned, most IK practices have not been recorded in written form. The knowledge is transmitted orally from one generation to the next. In this way, IK easily faces extinction due to lack of 
documentation. Among the leading reasons for the possible extinction of IK is that the focus has been on IK that has a direct cash value, thus ignoring the "non-cash" knowledge.

Less appreciation of IK today than there used to be in the past.Western-based knowledge has taken over in the education system. Anyone practicing IK as a means to obtain solutions, such as for medical problems, is looked down upon as outdated and primitive. Western medical technology has taken over. Similarly, many Tarok who live in big cities hardly ever bother to teach their children the values of their culture. Many will prefer to communicate with their children in English or some other dominant language used in the cities.

\section{Conclusion}

In summary, indigenous Tarok education is more practical than the kind of education brought by the missionaries. Indigenous type of education has a bearing to the traditions, norms and cultural beings to the society to which the children belong. Indigenous Tarok education is not well structured while western education is and it is bookish. Indigenous Tarok education gives a sense of belonging to the culture while the missionaries' kind of education does not.

\section{Recommendations}

The following recommendation is put forward with a view to improving the generation, collection, preservation and use of IK.

- IK training initiatives have to be developed to train people in IK principles and practices.

- Funding of IK

- Organizing annual cultural festivals

- Award and prizes

- Establishment of IK databases

- Establishment of IK resource centres (museum)

- Record IK to avoid the threat of extinction.

- IK should be integrated into the global knowledge system for its survival.

- The Tarok cultural organisation like the Ngwang I'shi O'Tarok and the women groups should initiate a programme of resuscitating the Tarok culture especially to the younger generations.

\section{References}

Abiola,. A \& Abiodun,. O (2017). Collection Development And Preservation Of Indigenous Knowledge In Selected Federal University Libraries In South West, Nigeria. Philosophy and Practice (e-journal) 1633

Aluwong,. Jeremiah (2019). Tribes in Nigeria: The Tarok People. https://connectnigeria.com/articles/2019/04/tribes-in-nigeria-the-tarok-people/Covin, T.J. \& Stivers, B. (1997). Knowledge management focus in US and Canadian firms. Creativity and Innovation Management, 63: pp140-150.

Edsand,. H \& Broich,. T (2019). The Impact of Environmental Education on Environmental and Renewable Energy Technology Awareness: Empirical Evidence from Colombia. International Journal of Science and Mathematics Education .Vol. 18, P611-634.

Johnson, M. (1992). Lore: Capturing traditional environmental knowledge. Ottawa, Canada: IDRC.

Lamle, E. N. (2005). Corporeality and Dwelling Spaces in Tarokland. Journal of Tarok studies: Nigerian Bible Translation Trust. Jos. 1 (1)pp 23 
Longtau, Selbut R., (1995). Tarok Ophresiology: An Investigation into the Tarok Terminology of Odour. In Issues in African Languages and Linguistics. Essays in Honour of Kay Williamson, ed. by E. NolueEmenanjo and Ozo-MekuriNdimele, pp. 340-344. Aba.

Makinde, O. O. \& Shorunke, O. A., (2013)."Exploiting the Values of Indigenous Knowledge in Attaining Sustainable Development in Nigeria: The place of the Library" Library Philosophy and Practice (e-journal).Paper 908.

Mkandawire, S. B. Silavwe, A. \&Mwewa, T. (2019).Understanding the Concept of Functional Literacy by Selected Residents of Lusaka District of Zambia.Journal of Lexicography and Terminology, 3 (2), 1 -30

Msoffe,. G. E. P. (2013). The Role of Indigenous Knowledge in Environmental Conservation and Climate Change Adaptation and Mitigation in Tanzania. http://www.suanet.ac.tz/cciam/

Nandip,. A (2016). From Africa: The Tarok Youth. Young Humanists International

Oxford Advance Learner's Dictionary 6 ed. / Edited by Sally Wehmwier, 2000 p.242.

Ranasinghe,. R (2015). The Transmission of Education across Generations: Evidence from Australia. The B.E. Journal of Economic Analysis \& Policy. Vol. 15: Issue 4.

Roger, B. \& Selbut, L. (1995) TarokOphresiology. Essays in Honour of Kay Williamson.Emenanjo, E.N. and Ndimele, O-M.eds. Aba, National Institute for Nigerian Languages. 340-344.

Yunus, H \& Yunus,. F (2017). Preservation of indigenous knowledge (IK) by public libraries in Westcliffe, Chatsworth, Durban. Thesis for: Masters in Library and Information Science.

Warren, D. M. (1991).“The Role of Indigenous Knowledge in Facilitating the Agricultural Extension Process". Paper presented at International Workshop on Agricultural Knowledge Systems and the Role of Extension. Bad Boll, Germany, May 21-24.

WHO traditional medicine strategy: 2014-2023". The World Health Organization. December 2013

Zuckermann, Ghil'ad; et al. (2015), ENGAGING - A Guide to Interacting Respectfully and Reciprocally with Aboriginal and Torres Strait Islander People, and their Arts Practices and Intellectual Property, Australian Government: Indigenous Culture Support, p. 7. 